\title{
THE PROTEINS OF BLOOD AND SUBCUTANEOUS LYMPH IN DOGS
}

\author{
By A. A. WEECH, E. GOETTSCH And E. B. REEVES
}

(From the Department of Diseases of Children of Columbia University College of Physicians and Surgeons, New York City)

(Received for publication June 17, 1933)

In the course of experiments undertaken to discover the effect of the flow and the composition of lymph on the formation of edema an opportunity has been afforded for comparing the albumin and globulin concentrations of blood serum with those of lymph serum obtained from lymphatics of the extremities of dogs. The comparison forms the basis of this communication.

\section{METHODS}

The dogs used were of mongrel breeds and varied in weight from 15 to 26 kilograms. Lymph was obtained through cannulas inserted into one of the lymphatic trunks just above the ankle of either a front or a hind leg. Cannulization was performed sometimes under ether anesthesia, sometimes under nembutal anesthesia and sometimes with the aid of a local anesthetic (novocaine) only. With animals under general anesthesia the flow of lymph was promoted by gentle massage of the foot and ankle and passive motion of the extremity. The non-anesthetized dogs were prepared by the method described by White, Field and Drinker (1) and allowed to walk about the corridors, the normal motion of the extremity furnishing the stimulus for lymph flow. A fine fibrin clot which formed in the lymph on standing was removed before analysis. Blood was obtained by puncture of the femoral artery usually at the end of the period of lymph collection and the serum separated as soon as possible. In several instances blood serum obtained both before and after the collection of lymph failed to indicate any change in composition during the experiment.

Methods of chemical analysis have been described in a previous paper (2). In some instances, because the quantities of lymph were limited, nonprotein nitrogen was determined on the serum only and the value so obtained used in calculating the lymph proteins. The error involved in such an assumption is small. In nine instances in which parallel determinations were made of lymph and serum nonprotein nitrogen, the average value for lymph was $24.5 \mathrm{mgm}$. per $100 \mathrm{cc}$. and for serum $22.7 \mathrm{mgm}$. per $100 \mathrm{cc}$. 


\section{ANALYTICAL RESLLTS}

The results of 25 parallel estimations of lymph and serum albumin and globulin made on specimens obtained from 13 dogs are shown in Table 1. A comparison of the albumin : globulin ratios is shown graphically in Chart 1. Table 1 shows that the $A / G$ ratios for serum varied from 0.5 to 2.0. The results may be regarded as accurate at least to the first decimal as the relatively high protein content of serum means that small analytical errors are not reflected in significant variations in the $\mathrm{A} / \mathrm{G}$ ratio. On the other hand the $\mathrm{A} / \mathrm{G}$ ratios for lymph varied between 0.1 and 3.0. In this case several specimens of lymph were encountered

TABLE 1

Proteins of blood serum and lymph from the legs of dogs

Data grouped by experiments and arranged roughly in ascending order of the total protein content of lymph

\begin{tabular}{|c|c|c|c|c|c|c|c|c|c|}
\hline \multirow{2}{*}{$\begin{array}{c}\text { Dog } \\
\text { num- } \\
\text { ber }\end{array}$} & \multicolumn{2}{|c|}{ Albumin } & \multicolumn{2}{|c|}{ Globulin } & \multicolumn{2}{|c|}{$\begin{array}{l}\text { Total } \\
\text { protein }\end{array}$} & \multicolumn{2}{|c|}{$\frac{\text { Albumin }}{\text { Globulin }}$} & \multirow{2}{*}{ Remarks*: } \\
\hline & Serum & Lymph & Serum & Lymph & Serum & Lymph & Serum & Lymph & \\
\hline & $\begin{array}{l}\text { grams } \\
\text { per } \\
100 \mathrm{cc} .\end{array}$ & $\begin{array}{l}\text { grams } \\
\text { per } \\
100 \mathrm{cc}\end{array}$ & $\begin{array}{l}\text { grams } \\
\text { per } \\
100 \mathrm{cc} .\end{array}$ & $\begin{array}{c}\text { grams } \\
\text { per } \\
100 \mathrm{cc}\end{array}$ & $\begin{array}{l}\text { grams } \\
\text { per } \\
100 \mathrm{cc} .\end{array}$ & $\begin{array}{c}\text { grams } \\
\text { per } \\
100 \mathrm{cc} \text {. }\end{array}$ & & & \\
\hline 5 & 1.36 & 0.05 & 1.88 & 0.17 & 3.24 & 0.22 & 0.72 & 0.29 & $\begin{array}{c}\text { Loc-Rl-Nutritional } \\
\text { edema }\end{array}$ \\
\hline 839 & 2.36 & 0.03 & 3.18 & 0.29 & 5.54 & 0.32 & 0.74 & 0.10 & Nem-Rl \\
\hline \multirow[t]{3}{*}{6} & 1.40 & 0.07 & 1.40 & 0.08 & 2.80 & 0.15 & 1.00 & 0.99 & $\begin{array}{l}\text { Nem-La-Plasmapher- } \\
\text { esis edema }\end{array}$ \\
\hline & 1.40 & 0.24 & 1.40 & 0.08 & 2.80 & 0.32 & 1.00 & 3.00 & $\mathrm{Ra}-$ Gentle \\
\hline & 1.40 & 0.28 & 1.40 & 0.41 & 2.80 & 0.69 & 1.00 & 0.69 & $\begin{array}{r}\mathrm{Ra} \text { - Vigorous } \\
\text { massage }\end{array}$ \\
\hline \multirow[t]{2}{*}{895} & 3.57 & 0.30 & 1.83 & 0.15 & 5.40 & 0.45 & 1.95 & 2.00 & $\mathrm{Nem}-\mathrm{R} 1$ \\
\hline & 3.57 & 0.48 & 1.83 & 0.27 & 5.40 & 0.74 & 1.95 & 1.78 & $\mathrm{La}$ \\
\hline 1000 & 2.34 & 0.21 & 3.36 & 0.57 & 5.70 & 0.78 & 0.70 & 0.37 & $\begin{array}{l}\text { E-3 hours after ether. } \\
\text { Dog walking }\end{array}$ \\
\hline \multirow[t]{2}{*}{949} & 2.99 & 0.53 & 3.05 & 0.50 & 6.04 & 1.03 & 0.98 & 1.06 & Nem-La-Veins con- \\
\hline & 2.99 & 0.44 & 3.05 & 0.29 & 6.04 & 0.73 & 0.98 & 1.52 & $\begin{array}{r}\text { La-Veins not } \\
\text { constricted }\end{array}$ \\
\hline \multirow[t]{4}{*}{58} & 3.44 & 0.49 & 2.26 & 0.30 & 5.70 & 0.79 & 1.52 & 1.63 & $\mathrm{E}-\mathrm{Ra}-$ Massage while \\
\hline & 3.44 & 0.6 & 2.26 & 0.3 & 5.70 & 1 & 1.52 & 1.73 & $\mathrm{Ra}-$ Dog walking \\
\hline & 3.44 & 0.60 & 2.26 & 0.3 & 5.70 & 0.90 & 1.52 & 2.00 & $\mathrm{Ra}-$ Dog running \\
\hline & 3.44 & 0.60 & 2.26 & 0.34 & 5.70 & 0.94 & 1.52 & 1.77 & $\begin{array}{l}\mathrm{Ra} \text { - Walking after } \\
\text { rest period }\end{array}$ \\
\hline
\end{tabular}


TABLE 1 (continued)

\begin{tabular}{|c|c|c|c|c|c|c|c|c|c|}
\hline \multirow{2}{*}{$\begin{array}{l}\text { Dog } \\
\text { num } \\
\text { ber }\end{array}$} & \multicolumn{2}{|c|}{ Albumin } & \multicolumn{2}{|c|}{ Globulin } & \multicolumn{2}{|c|}{$\begin{array}{c}\text { Total } \\
\text { protein }\end{array}$} & \multicolumn{2}{|c|}{$\frac{\text { Albumin }}{\text { Globulin }}$} & \multirow{2}{*}{ Remarks* } \\
\hline & Serum & Lymph & Serum & Lymph & Serum & Lymph & Serum & Lymph & \\
\hline & $\begin{array}{l}\text { grams } \\
\text { per } \\
100 \mathrm{cc} .\end{array}$ & $\begin{array}{c}\text { grams } \\
\text { per } \\
100 c c .\end{array}$ & \begin{tabular}{|} 
grams \\
per \\
$100 \mathrm{cc}$.
\end{tabular} & $\begin{array}{c}\operatorname{grams} \\
\text { per } \\
100 \mathrm{cc} .\end{array}$ & \begin{tabular}{|c|} 
grams \\
per \\
$100 \mathrm{cc}$.
\end{tabular} & \begin{tabular}{|} 
grams \\
per \\
$100 \mathrm{cc}$.
\end{tabular} & & & \\
\hline 69 & 3.50 & 0.68 & 2.27 & 0.58 & 5.77 & 1.26 & 1.54 & 1.17 & $\begin{array}{l}\text { E-After recovery, dog } \\
\text { walking }\end{array}$ \\
\hline \multirow[t]{4}{*}{840} & 3.08 & 0.97 & 1.99 & 0.52 & 5.07 & 1.49 & 1.55 & 1.86 & Loc-Rl-Massage \\
\hline & 3.08 & 0.96 & 1.99 & 0.45 & 5.07 & 1.41 & 1.55 & 2.13 & Rl-Walking \\
\hline & 3.08 & 1.16 & 1.99 & 0.49 & 5.07 & 1.65 & 1.55 & 2.37 & Rl-Running \\
\hline & 3.08 & 0.86 & 1.99 & 0.41 & 5.07 & 1.27 & 1.55 & 2.10 & $\begin{array}{c}\mathrm{Rl} \text {-Walking after } \\
\text { rest period }\end{array}$ \\
\hline 91 & 3.75 & 1.15 & 2.63 & 0.74 & 6.38 & 1.89 & 1.43 & 1.55 & $\begin{array}{c}\text { Loc-La-Mixture } \\
\text { walking and } \\
\text { running }\end{array}$ \\
\hline \multirow[t]{3}{*}{841} & 3.82 & 0.87 & 3.01 & 0.68 & 6.83 & 1.55 & 1.27 & 1.28 & $\mathrm{Nem}-\mathrm{Ra}$ \\
\hline & 3.82 & 1.14 & 3.01 & 0.91 & 6.83 & 2.05 & 1.27 & 1.25 & $\mathrm{La}$ \\
\hline & 3.82 & 1.35 & 3.01 & 0.82 & 6.83 & 2.17 & 1.27 & 1.22 & $\mathrm{Rl}$ and $\mathrm{Ll}$ \\
\hline 842 & 3.54 & 1.73 & 3.86 & 1.50 & 7.40 & 3.23 & 0.92 & 1.15 & $\begin{array}{r}\text { Nem-La-Veins con- } \\
\text { stricted }\end{array}$ \\
\hline 950 & 2.49 & 0.85 & 5.40 & 2.60 & 7.89 & 3.45 & 0.46 & 0.33 & Nem-La \\
\hline
\end{tabular}

* Abbreviations as follows: Nem $=$ nembutal anesthesia, $E=$ ether anesthesia, $L o c=$ local novocaine anesthesia, $L a=$ left fore leg, $R a=$ right fore leg, $L l=$ left hind leg, $R l=$ right hind leg.

in which the total protein concentration was less than 0.5 gram per cent and it is evident that small analytical errors in the analysis of such specimens produce wide variations in the $\mathrm{A} / \mathrm{G}$ ratios. Moreover, the ratios will increase in accuracy as the protein content of the specimen rises. $^{1}$ This factor of the accuracy of measurement has been given consideration in Chart 1 . Collectively considered there were 10 instances in which the serum ratio was greater than the lymph ratio and 15 examples of the reverse relationship. The average albumin : globulin ratio of all the lymph specimens analyzed was $1.41 \pm 0.09^{2}$ and the

${ }^{1}$ An example will render the magnitude of the possible analytical error more clear. Duplicate analyses of a lymph specimen show for total protein 0.38 and 0.42 gram per cent and for albumin 0.18 and 0.22 gram per cent. The $\mathrm{A} / \mathrm{G}$ ratio calculated from the average of the duplicate measurements is 1.00 and yet the individual measurements can be combined to give ratios which vary from 0.75 to 1.38 . An analytical variation of the same magnitude, occurring in serum with a protein content of 6.00 grams per cent, produces a ratio fluctuation between 0.98 and 1.02 only.

${ }^{2}$ Probable error of the mean. 


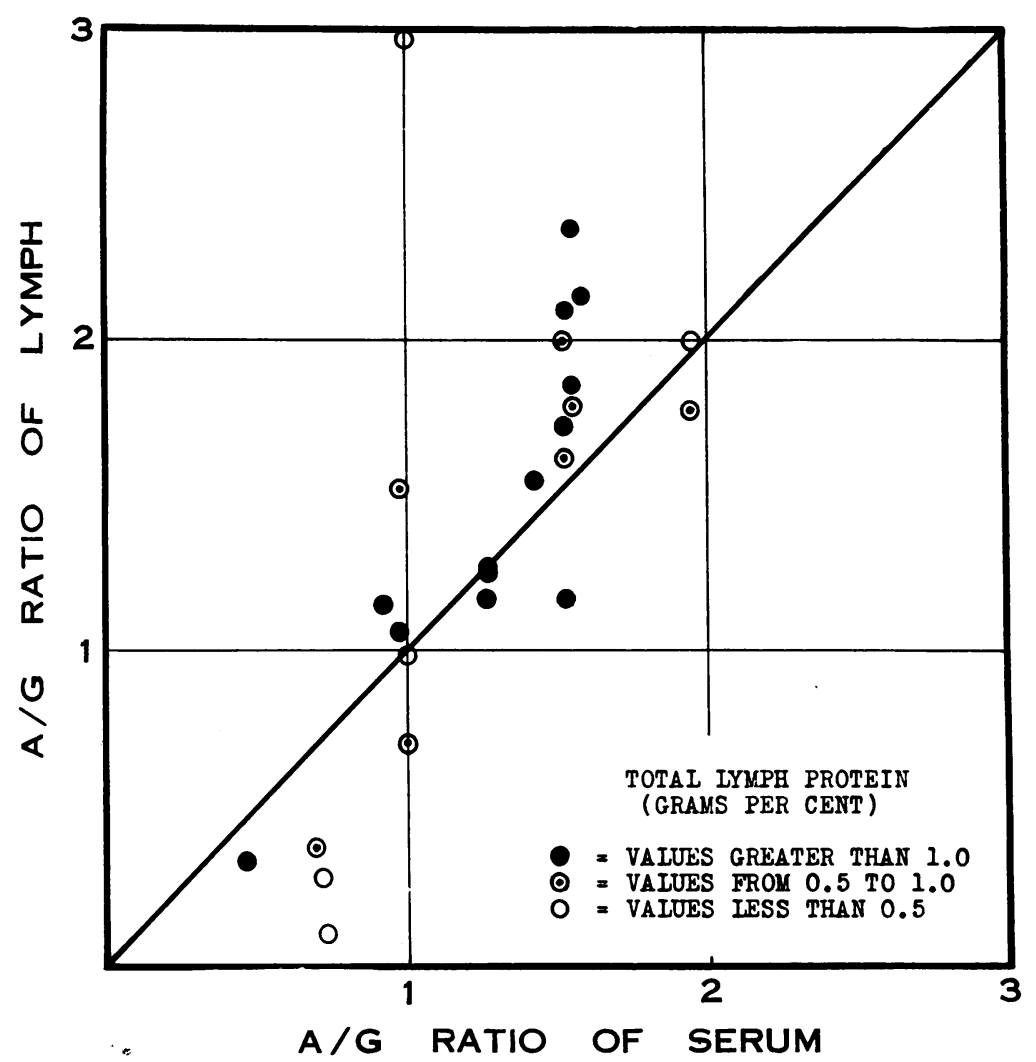

Fig. 1. Relationship Between the Albumin : Globulin Ratios of Blood Serum and Lymph from the Extremities in Dogs

The diagonal line follows the course of identity in the ratios and serves to emphasize the divergence of individual determinations from this identity.

corresponding average for the serums was $1.26 \pm 0.05 .^{2}$ A statistical calculation by the product-moment formula gives for the respective ratios a coefficient of correlation of 0.81 with a probable error of 0.05 . The correlation is sufficiently high to demonstrate a definite relationship between the albumin : globulin ratios of lymph and serum.

\section{DISCUSSION}

An examination of pertinent literature, tabulated exhaustively by Drinker and Field (3), discloses a great number of observations of the total protein content of lymph while at the same time revealing a paucity of information concerning the protein fractions which enter into its composition. In 1891 Munk and Rosenstein (4) reported two analyses of lymph obtained from the leg of an 18-year-old girl who was afflicted with progressive elephantiasis and who presented a permanent lymph fistula over the upper portion of her calf. Both analyses revealed a total 
protein concentration of 3.5 grams per cent; in one the albumin : globulin ratio was 4 and in the other 2.4. Simultaneous analyses of the serum proteins were not made. In 1906 Morawitz (5), in attempting to obtain information concerning the origin of the plasma proteins, made two experiments on dogs in which the proteins of plasma were compared with those of thoracic duct lymph. In the first experiment the blood serum showed an albumin : globulin ratio of 1.25 and the lymph serum a ratio of 1.56; in the second experiment the ratio for blood plasma was 1.44 and for lymph plasma 1.58. Although in both instances the lymph ratios were slightly higher than the blood ratios, the author did not regard the differences as significant. Finally in 1932 Wells (6) reported nine experiments in which the albumin : globulin ratios of serum were compared with those of lymph obtained from the mesenteric lacteals of dogs. The measurements revealed an average albumin : globulin ratio for serum of 1.18 , an average ratio for lymph of 1.39 , and agreed satisfactorily with direct estimations of the colloidal osmotic pressure. The analyses reported here are the first in which the protein fractions of serum have been compared with those of lymph from vessels which drain the subcutaneous tissues. Measurements of the colloidal osmotic pressure of serum and cervical lymph have, however, been reported by Loewen, Field and Drinker (7). The osmotic pressures per gram of lymph protein varied from 55 to $103 \mathrm{~mm}$. of water and in each instance were considerably higher than the corresponding pressures for serum protein. The excess pressure of lymph was thought to be an expression of greater permeability of the blood capillaries for serum albumin. An approximate calculation made by us on the basis of Govaerts' factors (8) indicates that several of the recorded pressures for cervical lymph are so high that they could not be accounted for even if all of the lymph protein were in the form of albumin. To explain them one would have to suppose either that lymph protein did not arise from serum protein or that the blood capillaries exhibit selective permeability for the smaller molecules of the albumin complex. A selective permeability of this nature is not in agreement with the analyses reported here.

The data reported in this paper show definitely that the albumin : globulin ratios of serum and lymph are mutually dependent variables and are thus in accord with the view of Drinker and Field $(3,9)$ that lymph protein is derived from blood protein. The correlation between the two variables is sufficiently high to indicate that the serum ratio is at least a major factor in establishing the lymph ratio. It does not exclude the possibility that minor factors, among them a slight degree of selective permeability on the part of the blood capillaries, may prevent identity in the proportions of proteins in the two fluids. Several of the grouped analyses obtained in single experiments in this study (particularly with dogs 58 and 840) strongly suggest the modifying influence of 
a mild degree of selective permeability for serum albumin; in other instances (dog 841) no such influence is apparent. The data also agree with those reported by Wells (6) in showing an average $A / G$ ratio for lymph slightly higher than that of the corresponding sera. We are not convinced, however, that justification exists for comparing analyses of lacteal lymph with those of subcutaneous lymph. The difference between the average ratios in this series is only 0.15 and, as this difference can be shown to have a probable error of 0.11 , final conclusions concerning selective filtration capacity of capillaries of the extremities must be deferred. This is especially true in view of the fact that we know of no simple way of accounting for those instances in which the lymph ratio was less than the serum ratio except by supposing both to result from variations within the limits of accuracy of the analytical methods employed.

The foregoing data have been presented and discussed chiefly because of their possible significance in assisting toward an understanding of the manner in which protein is transferred from the blood capillaries to the lymphatics. Two theories, both of which postulate that the capillary wall behaves as an ordinary sieve membrane, have appeared to us to be tenable. Since, as we shall see, the two theories lead to opposite conclusions concerning the composition of interstitial fluid and since it is in this composition that we are mainly interested, the theories will be outlined as briefly as is consistent with clarity.

The first theory does not concern itself primarily with a consideration of actual sizes of pores within the capillary membrane but contents itself with the assumption that the capillaries everywhere are somewhat permeable to protein. In this respect each capillary behaves like its neighbor; within a given area the rate of fluid filtration and the protein concentration of this fluid are essentially the same for the different capillary tufts. As a result the intercellular spaces outside the capillary wall become bathed in fluid the protein content of which is a rough measure of the degree of capillary permeability. It will be observed, however, that in the absence of some regulatory mechanism any degree, however slight, of capillary permeability for protein would in time lead to equilibrium of protein concentrations on the two sides of the membrane. For, with increases in pressure in the intercellular spaces accompanying the filtration of more and more fluid, the rate of filtration would be slowed and finally stop. And yet the passage of protein by diffusion would continue so long as the concentrations on the two sides of the membrane remained different. The regulatory mechanism is supplied by the lymphatic system which, by removing fluid mechanically from the interstitial spaces, prevents in a given lapse of time equality of protein concentration with the blood. The theory then assumes that lymph from any lymphatic trunk is representative in composition of interstitial 
fluid in the region drained by the trunk. Moreover, the more rapid the rate of flow, the more nearly will the composition of lymph indicate the composition of fluid leaving the capillaries when these are behaving as simple filters and therefore the more accurately measure the true degree of capillary permeability. This theory expresses the view of Drinker and Field $(3,9)$ as we have understood it. It can be brought into harmony either with the data reported in this paper which indicate that albumin and globulin are present in lymph in proportions not greatly different from those in serum or with the osmotic pressure measurements of Loewen, Field, and Drinker (7) which suggest a high degree of selective permeability on the part of the capillaries for the smaller albumin molecules of serum. In either case it is only necessary to assume the presence of pores in the membrane of a size which would explain the results obtained.

The first theory, just outlined, appears to us faulty only in failing to define more accurately the concept of the size of the pores and in disregarding conclusions which might be drawn from relatively wide variations in their normal diameters. The development of this concept constitutes the second theory. It will have been observed in connection with the first theory that the capacity of any membrane to yield a filtrate of lower protein concentration than the original colloidal suspension is tantamount to stating that the membrane contains pores of at least two sizes, both of which are permeable to the mother liquor but only one of which permits the passage of protein. If, then, the capillary wall is admitted to possess pores of two different diameters, it is not unreasonable to suppose the existence of pores of many different sizes and to suppose furthermore that by far the greatest number are distributed through a range of sizes too small to permit the passage of particles of colloidal dimensions. In fact, we may think that many, if not the majority, of individual capillary tufts are actually impermeable to protein. Now and again, however, larger pores may be found. A few of these may happen to be of such an intermediate size that they will permit the passage of albumin while holding back globulin but because the pores of intermediate size must be larger than the albumin molecule and smaller than the globulin molecule, a range which is relatively narrow, it follows that the chances are in favor of a greater number of large pores which exhibit no selective action for one or the other of the protein fractions. Whether pores of this large size are to be regarded as leaks, a term which suggests an abnormal condition of the capillary, is of no great importance. The evidence indicates that such leaks actually occur in all healthy animals and it seems more reasonable to regard them as extremes of a normal variation than to attach to them the stigma of abnormality.

If this theory expresses the state of affairs, it is pertinent to make 
inquiry concerning the distribution of the capillary filtrate. We have already suggested that a large proportion of capillary tufts may be impermeable to protein. These tufts will yield a protein-free ultrafiltrate, the volume of which will depend upon the balance of pressures operating across their walls, namely, the colloidal osmotic pressure in serum together with capillary blood pressure on the inside of each tuft and mechanical tension in the intercellular spaces on the outside. The latter tension may be suspected of varying under conditions which affect the mobility of fluid in adjacent lymphatics, being decreased when the pumping action of the lymphatic valves is stimulated by exercise or massage and increased when the valves are at rest. The factors controlling the volume of a filtrate are, therefore, multiple and it is easy to conceive of circumstances, some pathologic and others purely physiologic, under which it will increase greatly or practically vanish. For present purposes it is important to hold in mind that this group of capillary tufts will be surrounded by an interstitial fluid which is essentially protein free and that some of this fluid, at times much and at times little, will find its way into radicles of the lymphatic system. Across the walls of other capillaries, those for example which permit the passage of protein, the course of events will be considerably modified. These vessels will yield interstitial fluid rich in protein which will act to diminish the effective osmotic pressure of the intracapillary colloids and therefore to increase the volume of filtrate. This filtrate will likewise find its way into adjacent radicles of the lymphatic system. To what extent diffusion through neighboring intercellular spaces will occur is a matter of pure conjecture but it may be supposed that so long as the lymphatics offer the path of least resistance the major portion of filtrate will move by this route. Among a large group of lymphatic capillaries we may therefore imagine that many are carrying a centripetal stream of lymph of extremely low protein content and that a few are transporting fluid the protein concentration of which approaches that of the serum. The rate of lymph flow from the various radicles will, moreover, be more rapid in those which contain fluid of high protein concentration. Lymph, however, collected from any of the larger lymphatic trunks will represent a mixture of the streams coming from different radicles. Its composition may be expected to vary considerably as regards total protein content but the proportions of the several protein fractions should remain roughly the same as those in the serum of the same animal. An exceptional blood capillary which exhibited selective permeability for albumin molecules could produce a minute flow of this protein fraction into the general stream and so raise the $A / G$ ratio slightly above that in the blood. The theory then is consistent with the experimental observations being reported. It cannot, however, be reconciled with the readings of colloidal osmotic pressure of Loewen, Field, and Drinker (7) which indicate marked divergence between the $\mathrm{A} / \mathrm{G}$ ratios of serum and lymph. 
It will have been observed that the first theory, as outlined previously, can be identified in essential respects with the second if one supposes each individual blood capillary loop to possess pores the sizes of which cover the whole range of permeability which is assumed in the second theory for many capillaries. The distinction, however, is of fundamental importance for in the former instance one must imagine an interstitial fluid everywhere identical in composition with lymph and in the latter it can be thought that one very important function of the lymphatic system is to prevent interstitial fluid from attaining the relatively high protein concentrations of lymph. It is for this reason, chiefly, that the two theories have been outlined. Although either is consistent with the results reported, it seems desirable to insist that the available experimental evidence does not yet justify the conclusion that lymph as it is collected from a large lymphatic trunk is identical in chemical composition with interstitial fluid in the major portion of the region drained by the trunk.

\section{SUMMARY}

1. Experiments are reported in which the albumin and globulin concentrations in the serum of the blood are compared with those in lymph obtained from lymphatics of the legs of dogs.

2. In 25 parallel estimations of lymph and serum albumin and globulin the respective $A / G$ ratios showed a correlation coefficient of 0.81 with a probable error of 0.05 . The correlation is sufficiently high to demonstrate a definite relationship between the ratios of lymph and serum.

3. Two theories to account for the entrance of serum proteins into the lymphatics are discussed. The first supposes general permeability of the entire capillary network of the blood for protein and leads to the conclusion that interstitial fluid is everywhere identical in composition with the lymph which drains the area. The second assumes that occasional capillaries only permit the passage of protein, that this protein enters adjacent lymphatics at once, and that it never becomes disseminated throughout the intercellular spaces. The available evidence, including the findings in this investigation, although consistent with either theory, does not justify the conclusion that interstitial fluid and lymph are identical.

The authors wish to express their thanks to Dr. Cecil K. Drinker and Dr. Madeleine E. Field for their kindness in demonstrating the technique of cannulating lymphatics.

\section{BIBLIOGRAPHY}

1. White, J. C., Field, M. E., and Drinker, C. K., Am. J. Physiol., 1933, ciii, 34. On the Protein Content and Normal Flow of Lymph from the Foot of the Dog. 
2. Weech, A. A., Snelling, C. E., and Goettsch, E., J. Clin. Invest.; 1933, xii, 193. The Relation Between Plasma Protein Content, Plasma Specific Gravity and Edema in Dogs Maintained on a Protein Inadequate Diet and in Dogs Rendered Edematous by Plasmapheresis.

3. Drinker, C. K., and Field, M. E., Lymphatics, Lymph and Tissue Fluid. Williams and Wilkins Co., Baltimore, 1933.

4. Munk, I., and Rosenstein, A., Virchow's Arch. f. path. Anat., 1891, cxxiii, 230. Zur Lehre von der Resorption im Darm, nach Untersuchungen an einer Lymph(chylus-)fistel beim Menschen.

5. Morawitz, P., Beitr. z. chem. Physiol. u. Path., 1906, vii, 153. Beobachtungen über den Wiederersatz der Bluteiweisskörper.

6. Wells, H. S., Am. J. Physiol., 1932, ci, 421. The Concentration and Osmotic Pressure of the Proteins in Blood Serum and in Lymph from the Lacteals of Dogs.

7. Loewen, D. F., Field, M. E., and Drinker, C. K., Am. J. Physiol., 1931, xcviii, 70. The Colloid Osmotic Pressure of Dog Blood and Lymph.

8. Govaerts, P., Compt. rend. Soc. de biol., 1925, xciii, 441. Influence du rapport albumines-globulines sur la pression osmotique des protéines du sérum.

9. Drinker, C. K., and Field, M. E., Am. J. Physiol., 1931, xcvii, 32. The Protein Content of Mammalian Lymph and the Relation of Lymph to Tissue Fluid. 